\title{
The Research on College Students' Silence in the English Classroom
}

\author{
Xuehua Wang \\ School of Foreign Languages \\ Southeast University (SEU) \\ Nanjing, China \\ Wangxuehua@nuaa.edu.cn
}

\begin{abstract}
With the increase of international communications and competitions, the reticent language classroom has increasingly drawn researchers' attention. The key step to be taken to improve the learners' overall language proficiency is to change the traditional teaching ways, of which the prerequisite is to reconsider what contribute to learners' reticence in English class. It has be revealed through the study of special reasons of Mainland students' reluctance that the seeming reticence in English class is more likely to be the consequence of their learning habits that have been formed in the educational contexts for a long time than of any inherent dispositions of the learners themselves. Thus, the reticence can be altered though changing learners' habitual classroom behavior.
\end{abstract}

Keywords-reticence; english class; traditional teaching ways; mainland student

\section{INTRODUCTION}

Chinese students are alleged to be reticent in College English classroom in the recent ESL/EFL literature [1] $[2][3][4][5][6]$. The long-term existence of reticence in English learning has brought unfavorable effects on Chinese learners' English proficiency. Therefore, there is a necessity to change students' reticent behavior in English class, and an overall analysis on the various causes of such reluctance is the premise to achieve this goal.

\section{LITERATURE REVIEW}

Some researchers have been carried out to explore the causes for students' reluctance to adopt active roles in the English class. Maintaining the Integrity of the Specifications

Those findings have contributed a lot to the study on the reticent phenomenon, but Cheng's [5] conclusion lacks the empirical study, and the subjects of the researches carried out by Lin and Littlewood [6], Littlewood [9] and Jackson [3] on Chinese students are mainly restricted in Hong Kong district, while there are at least three aspects of differences in English learning environment between Hong Kong and Mainland areas: a) Roles of English in social life are different. According to Quirk's classification [10], Hong Kong lies in the outer circle of periphery varieties of English where English is widely used as a second language [4], while Mainland China is situated in the expanding circle of periphery varieties of English where English, as a foreign language, is learned in schools, but not used as a medium of instruction, nor as a language of communication [11]. b) Attitudes towards speaking English are different. c) Ways of testing in schools are different.

With the Mainland college students as the main subjects, the present research is to make an overall analysis of various causes behind the reticence with the aim to see whether the phenomenon of the students' reluctance in the college English classroom can be changed.

\section{EXPERIMENT DESIGN}

In order to be able to gain access to the opinions of a large and potentially diverse population, it was decided to use questionnaires, one for students and the other for teachers, as the main research instrument. And a Likert scale from 1 to 6 is used as " 1 " for "Stongly agree" and " 6 " for "Stongly disagree".

\section{PRESENTATION AND Discussion OF RESUlts}

\section{A. Learner's Habitual Classroom Behavior}

It is not beyond expectation that almost all the means in this part are above 3.5 (see Table I) as reticence and passivity is regarded to be of wide existence: students do not ask questions (item 2); not share their ideas (item 3); not question others (items 4 and 5). However, the mean of 2.98 and 2.76 from both students and teachers about the statement "participate in classroom activities actively" (item 1) shows that both the learners and teachers regard learners' classroom behavior as active one though there is a wide allegation of reticence. Thus the results bring us a very worthwhile reconsideration of what is "active classroom participation" in Mainland learners and teachers' eyes. From the data, we can infer that in the Mainland context, learners might participate in classroom activities "actively" by paying attention "quietly” to what is going on in the classroom and concentrating on what they need to learn. 
TABLE I. COLLEGE STUDENTS’ BEHAVIOR IN COLLEGE ENGLISH CLASS

\begin{tabular}{|c|c|c|c|}
\hline \multicolumn{2}{|c|}{ Classroom Behavior } & $\begin{array}{c}\text { Mean of } \\
\text { students }\end{array}$ & $\begin{array}{c}\text { Mean of } \\
\text { teachers }\end{array}$ \\
\hline 1 & Participate in classroom activities \\
actively. & 2.98 & 2.76 \\
\hline 2 & $\begin{array}{c}\text { I raise questions the minute I } \\
\text { encounter them. }\end{array}$ & 3.91 & 3.90 \\
\hline 3 & I am eager to share my ideas. & 3.66 & 3.63 \\
\hline 4 & $\begin{array}{c}\text { I will question him/her if I hold a } \\
\text { different view from the teacher's. }\end{array}$ & 3.96 & 3.60 \\
\hline 5 & $\begin{array}{c}\text { I will question them if I hold a } \\
\text { different view from my classmates'. }\end{array}$ & 3.14 & 3.68 \\
\hline
\end{tabular}

\section{B. Main Causes of Reticence}

Among all the listed causes, Table II shows only those which score a mean of below 3.5

It is suggested, in the light of the similar order of the mean from teachers' response, that the students and the teachers share an agreement to some extent on the issue. Previous learning experience (cause 1), to which most importance has been attached here, reveals all that the students are supposed to do in the traditional class. These are presumably the characteristics of Chinese Confucian culture and tradition (cause 6). The finding is consistent with that of other researchers [12][7] who concluded that reticent and passive behavior results from certain cultural attitudes of Asian societies. However, respecting knowledge and knowledgeable persons does not mean that students should be compliant and passive to the teacher. Thus Confucian culture does not seem to be a convincing cause for Chinese students' reticence in class, that is to say, Chinese students are not born to adopt the passive classroom attitude.

Causes 2 and 3 as linguistic factors reveal the difficulty the teachers meet with to make the teaching tasks comprehensible and workable in consideration of students' current language competence of all levels. The other causes contributed to the reticence like anxiety, introvert personality and motivation (causes 4, 5 and 7) are similar to the discoveries of Tsui [4], Liu \& Littlewood [6] Jackson [3].

TABLE II. COLLEGE STUDENTS’ AND TEACHERS` VIEWS OF CAUSES WHICH RESULT IN RETICENCE IN ENGLISH CLASS

\begin{tabular}{|c|l|c|c|}
\hline \multicolumn{2}{|c|}{$\begin{array}{c}\text { Causes (arranged in a rising order of the } \\
\text { mean of students) }\end{array}$} & $\begin{array}{c}\text { Mean of } \\
\text { students }\end{array}$ & $\begin{array}{c}\text { Mean of } \\
\text { teachers }\end{array}$ \\
\hline 1 & Previous learning experience & 2.32 & 1.98 \\
\hline 2 & Lack of required language proficiency & 2.48 & 2.38 \\
\hline 3 & Uninteresting teaching content & 2.99 & 3.16 \\
\hline 4 & $\begin{array}{l}\text { Anxiety of making mistakes, losing } \\
\text { face }\end{array}$ & 3.05 & 2.27 \\
\hline 5 & Introvert personality & 3.17 & 2.74 \\
\hline 6 & $\begin{array}{l}\text { Result of Chinese Confucian culture } \\
\text { and tradition }\end{array}$ & 3.17 & 2.76 \\
\hline 7 & $\begin{array}{l}\text { Lack of motivation of learning } \\
\text { English well }\end{array}$ & 3.29 & 3.26 \\
\hline
\end{tabular}

\section{Learners' Desire of Adopting A More Active Role in Classroom Activities}

The data from Table III indicate that students in Mainland China are quiet, passive participators, which is likely to be a result of the traditional educational environment. However, similar to the findings of Jackson [3], Cheng [5], Littlewood [8] and Liu and Littlewood [6], the data from the questionnaires also suggest that learners do not want to remain in their shells. Instead, they hunger to be involved in "overt talk", namely, they are ready to adopt a more active role. Table IX reflects such eagerness from different aspects.

TABLE III. LEARNERS' DESIRE OF ADOPTING A MORE ACTIVE ROLE IN CLASSROOM ACTIVITIES

\begin{tabular}{|c|c|c|c|}
\hline \multicolumn{2}{|c|}{$\begin{array}{c}\text { Learners' desire of adopting a more active } \\
\text { role in classroom activities }\end{array}$} & $\begin{array}{c}\text { Mean of } \\
\text { students }\end{array}$ & $\begin{array}{c}\text { Mean of } \\
\text { teachers }\end{array}$ \\
\hline 1 & $\begin{array}{c}\text { A lot of attention is paid to improving oral } \\
\text { communicative competence. }\end{array}$ & 1.81 & 2.32 \\
\hline 2 & $\begin{array}{c}\text { More communicative activities, e.g. role } \\
\text { play and discussion, are contained in } \\
\text { classroom teaching. }\end{array}$ & 2.32 & 2.01 \\
\hline 3 & $\begin{array}{c}\text { Learner-centered instruction and learners' } \\
\text { participation are encouraged. }\end{array}$ & 1.99 & 1.64 \\
\hline 4 & Group work (group of 3 or 5) is advocated. & 2.40 & 2.05 \\
\hline 5 & $\begin{array}{c}\text { The teacher explains the learning purpose of } \\
\text { class activities. }\end{array}$ & 2.62 & 2.34 \\
\hline 6 & $\begin{array}{c}\text { The relaxed classroom atmosphere is } \\
\text { important for English speaking practice. }\end{array}$ & 1.52 & 1.66 \\
\hline 7 & $\begin{array}{c}\text { Knowledge is something that the teacher } \\
\text { should pass on to learners rather than } \\
\text { something learners should discover } \\
\text { themselves. }\end{array}$ & 4.82 & 4.90 \\
\hline 8 & $\begin{array}{c}\text { Teachers are expected (rather than learners } \\
\text { themselves) to be responsible for evaluating } \\
\text { how much learners have learned. }\end{array}$ & 3.90 & 3.48 \\
\hline
\end{tabular}

Both the learners and the teachers' responses clearly indicate that the stereotype of Chinese students as "quiet, passive learners" does not reflect the role they would like to adopt in class. They do not want to receive knowledge passively (item 7, mean>3.5); they do not expect to be evaluated only by teachers (item 8 , mean $>3.5$ ); they see the importance of knowing the learning purpose of the classroom activities (item 5, mean<2.5); and they express their strongly positive attitude to communicative activities that they are actively engaged in (items 1,2 and 3 , mean $<2.5$ ). The preferences are consistent with the characteristic which Littlewood [9] found in Hong Kong students that learners may feel more relaxed when they work in small groups than when the whole class works together (c.f. items 4 and 6, mean $<2.5$ ).

Learners' strong desire of participating actively in classroom activities is also stirred by their high motivation of learning English well with all the means of below 3.5 (see Table IV). In particular, the data show that students have strong instrumental motivation driven by career pursuing (item 1) and national English test (item 2), and not weak integrative motivation of appreciating the sound of the English language (item 3), which is consistent with the findings of Fang [14]. 
TABLE IV. LEARNERS’ MOTIVATION OF LEARNING ENGLISH WELL

\begin{tabular}{|c|c|c|c|}
\hline \multicolumn{2}{|c|}{ Learners' motivation of learning English } & $\begin{array}{c}\text { Mean of } \\
\text { well }\end{array}$ & $\begin{array}{c}\text { Mean of } \\
\text { teachers }\end{array}$ \\
\hline 1 & $\begin{array}{c}\text { I learn English in order to improve my } \\
\text { career prospects. }\end{array}$ & 2.04 & 2.66 \\
\hline 2 & A lot of attention is paid to CET-4. & 2.44 & 3.50 \\
\hline 3 & I like the sound of the English language. & 2.78 & 3.81 \\
\hline 4 & $\begin{array}{c}\text { Learning English enables me to see and } \\
\text { understand the world in a different way. }\end{array}$ & 2.91 & 2.40 \\
\hline 5 & $\begin{array}{c}\text { English is the sign of an educated person } \\
\text { in China }\end{array}$ & 3.05 & 2.97 \\
\hline 6 & $\begin{array}{c}\text { The use of English is one of the most } \\
\text { important factors that have contributed to } \\
\text { China's development. }\end{array}$ & 3.26 & 3.11 \\
\hline
\end{tabular}

\section{CONCLUSION}

From the above data presentation and discussion, we can get the following conclusions:

Learners' previous learning experience, apart from other linguistic and affective factors, is regarded as the most important cause of learners' reticence in English class. Such learning experience has been formed not in the Confucian Culture in Mainland China, but in the traditional learning environment where the Grammar-Translation Method plays a major role. In other words, Mainland students' reticence is more likely to be the performance of their habitual classroom behaviors that have been formed in the traditional learning circumstances than to be the consequence of any inherent dispositions of the students themselves. This is consistent with Littlewood's finding [9] from the empirical study on Hong Kong students and Cheng's conclusion [5]from literature study on Asian students. So reticence can be changed if the learning environment alters.

Mainland students and teachers have their own concept of "active participation" which includes not only overt talk but also quiet attentiveness. So it is equally important to improve the degree and the conception of classroom participation for the sake of alleviating reticence in English class.

Though quiet attentiveness is considered as "active participation", students express positive attitudes towards overtly active participation in classroom activities and high motivation to learn English well despite some linguistic difficulties for them. That is, students would like to play a more active role, if the learning environment allows or encourages it.
The further research might conduct a new teaching approach to change the reticence in College English classroom based on the above questionnaire data analysis and the correspondent conclusions.

\section{ACKNOWLEDGEMENT}

The paper is supported by the Special fund entitled "A Study on the Transition of College English Teaching Oriented towards EAP” for the Fundamental Research Funds for the Central Universities, 2012, under contract number SKCX20120025)

\section{REFERENCES}

[1] Chen, T. 2003. Reticence in class and on-line: two ESL students' experiences with communicative language teaching. System,31: 259-281.

[2] Rao, Z. 2002. Chinese students' perceptions of communicative and noncommunicative activities in EFL classroom. System, 30:85-105.

[3] Jackson, J. 2002. Reticence in second language case discussions: anxiety and aspirations. System, 30:65-84.

[4] Nunan, D. 2001. Second language teaching and learning. Beijing: Foreign Language Teaching and Research Press.

[5] Cheng, X. 2000. Asian students' reticence revisited. System, 28: 435446.

[6] Liu, N., \& W. Littlewood. 1997. Why do many students appear reluctant to participate in classroom learning discourse. System, 25/3: 371-384.

[7] Ferris, D., \& T. Tagg. 1996. Academic listening/speaking tasks for ESL students: problems, systems, and implications. TESOL Quarterly, 30/2:297-320.

[8] Littlewood, W. 2000. Do Asian students really want to listen and obey? ELT Journal 54/1: 31-36.

[9] Littlewood, W. 2004. Students' perspectives on interactive learning. In J. Jones, O. Kwo \& T. Moore (eds.) Developing learning environment in higher education. Hong Kong: Hong Kong University Press.

[10] Zhang, Y., \& Q. Zhang. 2004. Globalization of English and teaching EFL in China. CELEA Journal, 27/5: 22-26.

[11] Hu, Z., R. Liu, , \& Y. Li. (eds.) 1998. Linguistics: A course book. Beijing: Beijing University Press.

[12] Flowerdew, J., \& L. Miller. 1995. On the notion of culture in L2 lectures. TESOL Quarterly, 29/2:345-373.

[13] Richards, J.C., \& T. S. Rodgers. 1996. Approach and methods in language teaching. Cambridge: Cambridge University Press.

[14] Fang, F. (2006). My experience of learning languages and teaching English in China - A narrative inquiry. English Teaching: Practice and $\begin{array}{ll}\text { Critique. } & \text { 5/2: }\end{array}$ http:/education.waikato.ac.nz/research/files/etpc/2006v5n2nar2.pdf 